Part II. Physical activity of social and professional groups

Dział II. Aktywność fizyczna grup społecznych i zawodowych

\title{
NUTRITIONAL HABITS AND PHYSICAL ACTIVITY OF THE YOUTH OF LATVIA CONSIDERING GENDER DIFFERENCES
}

\section{ZACHOWANIA ŻYWIENIOWE I AKTYWNOŚĆ FIZYCZNA MŁODZIEŻY ŁOTEWSKIEJ Z UWZGLĘDNIENIEM PŁCI}

\author{
Angelina Ignatjeva ${ }^{1(B, C, D, F)}$, Józef Bergier ${ }^{2(A, C, D, E)}$
}

\author{
${ }^{1}$ Ita Kozakiewicz High School in Riga, Latvia \\ ${ }^{2}$ Pope John Paul II State School of Higher Education in Biała Podlaska, Poland
}

Authors' contribution Wkład autorów:

A. Study design/planning zaplanowanie badań

B. Data collection/entry zebranie danych

C. Data analysis/statistics dane - analiza i statystyki D. Data interpretation interpretacja danych E. Preparation of manuscript przygotowanie artykułu F. Literature analysis/search wyszukiwanie i analiza literatury G. Funds collection zebranie funduszy

Tables: 10

Figures: 4

References: 30

Submitted: 04.02.2016

Accepted: 28.04.2016

\begin{abstract}
Summary
Introduction. Nutritional habits and physical activity are fundamental for a healthy lifestyle. The aim of the paper is to present differences in the area of important pillars of health taking into account youth's gender.

Material and methods. The research was conducted on Polish high school students in Riga, Latvia. The diagnostic survey method was used with International Physical Activity Questionnaire - IPAQ's short version and the Health Behaviour Questionnaire.

Results. There are major differences in health behaviour between girls and boys, including willingness to lose and gain weight, various motives for exercising to gain or lose body weight and the fear of weight gain.

The field of physical activity regarding greater activity and participation in intensive exercises was dominated by boys.

Conclusions. The school process of eating habits education and physical activity should be modified.

Keywords: youth of Latvia, nutritional habits, physical activity, gender

Streszczenie

Wprowadzenie. Zachowania żywieniowe i aktywność fizyczna stanowią podstawę zdrowego stylu życia. Celem pracy było wykazanie występowania różnic w obrębie tych ważnych filarów zdrowia w zależności od płci młodzieży.

Materiał i metody. Badaniami objęto młodzież licealną szkół polskich w Rydze na Łotwie. Zastosowano metodę sondażu diagnostycznego $\mathrm{z}$ wykorzystaniem Międzynarodowego Kwestionariusza Aktywności Fizycznej - IPAQ w wersji krótkiej oraz kwestionariusza zachowań zdrowotnych.

Wyniki. Wykazano znaczące różnice $\mathrm{w}$ zachowaniach zdrowotnych między dziewczętami i chłopcami w tym, w chęci schudnięcia i przytycia, innych motywów stosowania ćwiczeń w celu zwiększenia lub zmniejszenia masy ciała oraz strachu przed przytyciem. W zakresie aktywności fizycznej wykazano znacząco większą aktywność i większy udział

w intensywnych wysiłkach wśród chłopców. Wnioski. Należy modyfikować szkolny proces edukacyjny w zakresie roli zachowań żywieniowych i aktywności fizycznej.
\end{abstract}

Słowa kluczowe: młodzież łotewska, zachowania żywieniowe, aktywność fizyczna, płeć

\section{Introduction}

Nutritional habits and physical activity are the pillars of a healthy lifestyle. Appropriate nutritional habits, that is regularity, quality and quantity of eaten meals during a day adjusted to body's needs as well as systematic physical activity have major impact on health, mental and physical development of children and youth [1,2]. One of the fundamental principles of a good diet for children and youth is eating nutritious and little processed meals 4-5 times a day and avoiding snacks between meals. The most important meal should be nutritious breakfast that will cover $20-25 \%$ of daily body energetic requirement. Consumption of breakfast before going out from home guarantees better concentration and comfort during school time [3]. The research conducted in Poland shows many abnormalities about the way of nutrition of schools' youth, including: irregular meal eating, having snacks between meals, increased amount of eaten sweets, sugary soda's and fast foods [4,5,6,7,8,9]. 
The research of physical activity among children and youth indicates that one of the reasons of their low activity is civilizational progress. The influence of new technologies alters the way of spending free time. Students' organisms perform more mental exercises than physical ones, which leads to energy accumulation in the organism. Use of cell phones, computers and internet is connected with a long immobilisation and because of the attractiveness of these inventions - they compete with physical activity [10].

Observations of changes in Polish students' physical activities to the end of 90's allow to claim that their level is getting lower with ageing and is permanently lower than recommended [11]. Therefore, following changes in physical activities of youth is still vital and the results have special value when obtained with the use of same research method. Contemporarily recommended tool is International Physical Activity Questionnaire (IPAQ) that has been used by many scholars in many researches in Poland $[12,13,14,15,16]$.

The works of Wasilewska, Bergier [17] are worth mentioning because of using the questionnaire among school youth in other countries $[18,19,20,21,22,23,24]$. Among researches on current nutritional habits and physical activities it is essential to show their differentiation by gender.

The aim of the paper is to show differences in nutritional habits and physical activity of the youth of Latvia considering gender differences.

\section{Methods and materials of research Material of research}

The research was conducted in May 2014 on the group of 150 students ( 62 girls - 48\% and 88 boys - 52\%) in two Polish high schools: in the Ita Kozakiewicz High School in Riga and High School no. 87 in Riga, Latvia.

The research group was proportionally divided by age of students. The age of $18-34 \%$, and at the age of 17 and $16-33 \%$.

\section{Methods and organization of research}

The research method was the diagnostic survey, and the measurement tool was International Physical Activity Questionnaire - IPAQ's short version. It is one of the most commonly used questionnaires in survey research of physical activity, recommended, among others, by European Physical Activity Surveyance System (EUPASS) and European Health Interview Survey (EUROHIS). In numerous studies a satisfactory repetitiveness (reliability) and validity (accuracy) of this measurement tool was confirmed while confronted with objective measurement devices (accelerometer, pedometer) $(25,26)$.

On the basis of the physical activity self-evaluation results by IPAQ questionnaire of boys and girls, a weekly level of it was determined in the three zones of effort's intensity using unit METmin $\times$ week. -1 . The calculation procedure relied on multiplying an average physical activity duration time per day by number of days it was undertaken and the MET's value for a given zone of effort's intensity. Total weekly amount of physical activity of subjects (WPA) was designated by summing up its level in three intensity zones.

The studied boys and girls were assigned to highly, sufficient and not sufficient physically active groups, taking criteria acknowledged by International Committee IPAQ [27] into consideration.

For each parameter of physical activity the basic descriptive statistics parameter was assigned: arithmetical means $(\bar{x})$, standard deviations (SD) and variation coefficient (V). In order to determine a significance of differences between average results of girls and boys self-evaluation the $t$ Student tests were conducted for independent samples.

The results of research were statistically analysed by Statistica v. 7.1 software. For every kind of physical activity there were calculated basic descriptive statistics (arithmetic mean and standard deviations). In order to determine the dependencies that are statistically significant for features measured in nominal value the Chi-square test was used. In other case (for quantitative scale) the nonparametric tests U Mann-Whitney and Kruskal Wallis were used. In all analysed cases the level of significance p=0,05 was assumed.

\section{Research results}

\section{Students' nutritional habits}

\section{The need tolose/gain weight}

In the girls' group $82.3 \%$ of students wanted to lose weight, while $17.7 \%$ did not intend to do so. In the case of boys, $71.6 \%$ did not want to lose weight, whereas $28.4 \%$ wanted to lose weight. It has been shown that there is a significant differentiation about the issue of losing weight among girls (Tab. 1, Fig. 1). 
Among girls, $96.8 \%$ did not wantto gain weight, while only 2 people (3.2\%) wanted to increase their body weight. Whereas, $84.1 \%$ of boys did not want to gain weight, while only $15.9 \%$ wanted to increase their body weight. Boys significantly more often wanted to gain weight than girls (Tab. 2, Fig. 2).

Table 1. Have you ever wanted to lose weight?

\begin{tabular}{|c|c|c|c|}
\hline \multirow{2}{*}{ Gender } & \multicolumn{2}{|c|}{ Have you ever wanted to lose weight? } & \multirow{2}{*}{ Gender differentiation } \\
\cline { 2 - 3 } & Yes & $11(17.7 \%)$ & \multirow{2}{*}{$\begin{array}{c}\chi 2=59.07 \\
\mathbf{p}<\mathbf{0 . 0 0 0 1} *\end{array}$} \\
\hline Girls & $51(82.3 \%)$ & $63(71.6 \%)$ & \\
\hline Boys & $25(28.4 \%)$ & $74(49.3 \%)$ & \\
\hline Total & $76(50.7 \%)$ & & \\
\hline
\end{tabular}

*-significant differences with $\mathrm{p}<0.05$

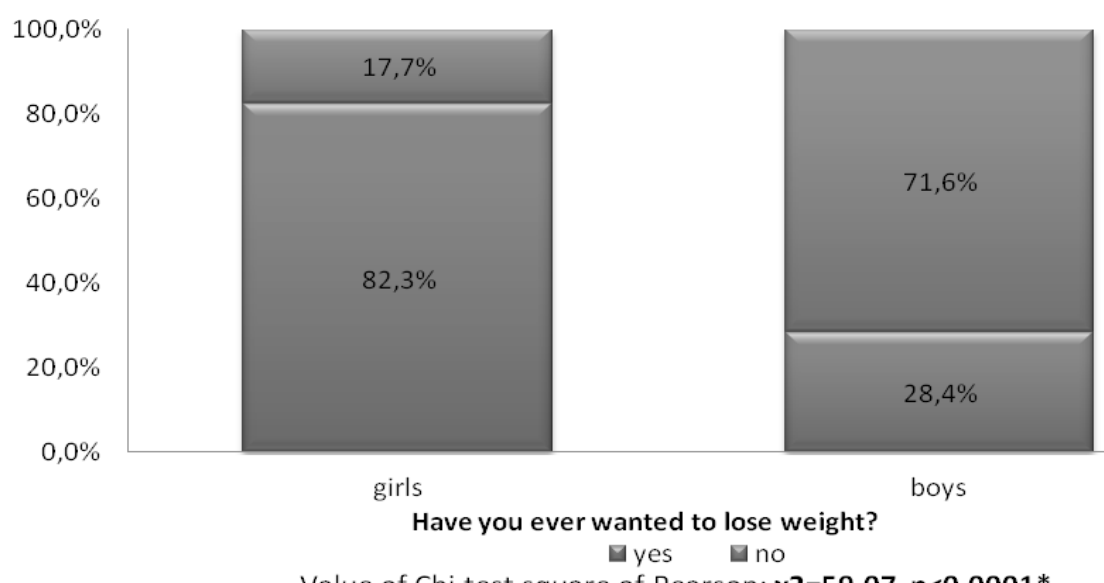

*-significant differences with $\mathrm{p}<0.05$

Value of Chi test square of Pearson: $\chi 2=59,07 \mathrm{p}<0,0001 *$

Figure 1. Have you ever wanted to lose weight?

Table 2. Have you ever wanted to gain weight?

\begin{tabular}{|c|c|c|c|}
\hline \multirow{2}{*}{ Gender } & \multicolumn{2}{|c|}{ Have you ever wanted to gain weight? } & \multirow{2}{*}{ Gender differentiation } \\
\cline { 2 - 3 } & Yes & No & \multirow{2}{*}{$\begin{array}{c}\mathbf{2}=\mathbf{9 . 8 4} \\
\mathbf{p = 0 . 0 0 1 7}\end{array}$} \\
\hline Girls & $2(3.2 \%)$ & $70(96.8 \%)$ & \\
\hline Boys & $14(15.9 \%)$ & $134(84.1 \%)$ & \\
\hline Total & $16(10.7 \%)$ & $(89.3 \%)$ & \\
\hline
\end{tabular}

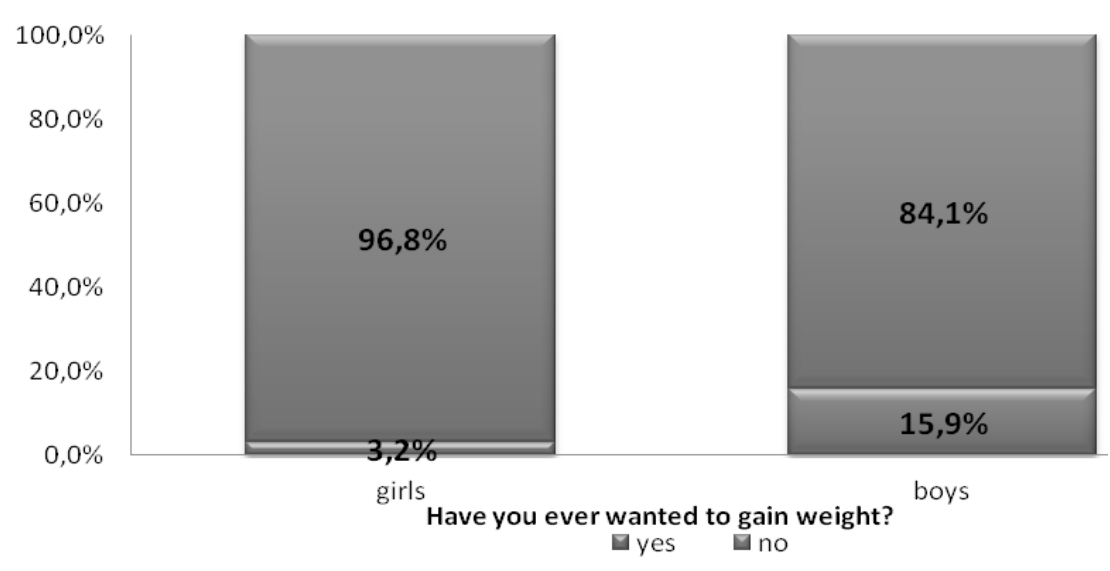

*-significant differences with $\mathrm{p}<0,05$

Value of Chi test square of Pearson: $\mathbf{\chi 2}=\mathbf{9 , 8 4} \mathrm{p}=\mathbf{0 , 0 0 1 7}$ *

Figure 2. Have you ever wanted to gain weight? 


\section{Nutrition-related behaviour}

Nutrition-related behaviour by gender has been shown in Table 3. In the girls' group, $81.4 \%$ of them were characterized as controlling the food intake, while $18.6 \%$ were not controlling it. The ratio among boys and girls was similar (no significant differences). Among boys $89.5 \%$ claimed to take control over the intake of food and $10.5 \%$ claimed otherwise. The fear of gaining weight was significantly more often present among girls (76.3\%) than boys (50.5\%). Nutritional habits that involved forcing vomiting were residual and appeared only among $1 \%$ of respondents. Avoiding eating occurred only among several percent of respondents and was not found to be different according to gender. The indicator of irregular nourishment occurred among $25.2 \%$ of students, and despite the fact that it was higher among boys (30.5\%) than girls (19.6\%) the difference was not statistically significant (Tab. 3).

Table 3. Nutrition-related behaviour by gender

\begin{tabular}{|c|c|c|c|}
\hline \multicolumn{4}{|c|}{ Losing control over the food intake } \\
\hline Gender & No & Yes & Statistics \\
\hline Girls & $81.4 \%$ & $18.6 \%$ & \multirow{3}{*}{$\begin{array}{c}X^{2}=2.68 \\
p=0.1018\end{array}$} \\
\hline Boys & $89.5 \%$ & $10.5 \%$ & \\
\hline Total & $85.6 \%$ & $14.4 \%$ & \\
\hline \multicolumn{4}{|c|}{ Fear of weight gain } \\
\hline Gender & No & Yes & Statistics \\
\hline Girls & $23.7 \%$ & $76.3 \%$ & \multirow{3}{*}{$\begin{array}{c}X^{2}=14.39 \\
\mathbf{p}=\mathbf{0 . 0 0 0 2}\end{array}$} \\
\hline Boys & $49.5 \%$ & $50.5 \%$ & \\
\hline Total & $37.1 \%$ & $62.9 \%$ & \\
\hline \multicolumn{4}{|c|}{ Forcing vomiting } \\
\hline Gender & No & Yes & Statistics \\
\hline Girls & $99.0 \%$ & $1.0 \%$ & \multirow{3}{*}{$\begin{array}{c}X^{2}=0.26 \\
p=0.6080\end{array}$} \\
\hline Boys & $98.1 \%$ & $1.9 \%$ & \\
\hline Total & $98.5 \%$ & $1.5 \%$ & \\
\hline \multicolumn{4}{|c|}{ Avoiding eating } \\
\hline Gender & No & Yes & Statistics \\
\hline Girls & $88.7 \%$ & $11.3 \%$ & \multirow{3}{*}{$\begin{array}{c}\mathrm{X}^{2}=1.38 \\
\mathrm{p}=0.2400\end{array}$} \\
\hline Boys & $82.9 \%$ & $17.1 \%$ & \\
\hline Total & $85.6 \%$ & $14.4 \%$ & \\
\hline \multicolumn{4}{|c|}{ Irregular nourishment } \\
\hline Gender & No & Yes & Statistics \\
\hline Girls & $80.4 \%$ & $19.6 \%$ & \multirow{3}{*}{$\begin{array}{c}X^{2}=3.17 \\
p=0.0751\end{array}$} \\
\hline Boys & $69.5 \%$ & $30.5 \%$ & \\
\hline Total & $74.8 \%$ & $25.2 \%$ & \\
\hline
\end{tabular}

*-significant differences with $\mathrm{p}<0,05$

\section{Agents used to improve shape}

In the girls' group $88.7 \%$ exercised in order to lose body weight, while $11.3 \%$ did not do such exercises. Boys statistically significantly less frequently exercised in order to lose body weight - only $16.2 \%$ of them did so. The opposite regularity was present among genders in case of exercising in order to increase body weight. Boys significantly more frequently performed such exercises (90.5\%) than girls (12.4\%). Among other types of agents used to improve shape there were very little values: weight control medication and diuretics $-3.5 \%$, laxatives $-2.5 \%$, body weight increase medication $-1.5 \%$, anabolic steroids $-0.5 \%$. The low results of the above indicate a good trend among the students and prove that they are aware about their own health (Tab. 4).

Table 4. Agents used to improve shape by gender

\begin{tabular}{|c|c|c|c|}
\hline \multicolumn{3}{|c|}{ Physical exercises done in order to lose body weight (eg. running, cycling, fitness) } \\
\hline Gender & No & Yes & Statistics \\
\hline Girls & $11.3 \%$ & $88.7 \%$ & \multirow{2}{*}{$\mathrm{X}^{2}=105.96$} \\
\hline Boys & $83.8 \%$ & $16.2 \%$ & \multirow{2}{*}{$\mathbf{p 0 . 0 0 1}^{*}$} \\
\hline Total & $49.0 \%$ & $51.0 \%$ & \\
\hline
\end{tabular}




\begin{tabular}{|c|c|c|c|}
\hline \multicolumn{4}{|c|}{ Physical exercises done to increase muscle mass (eg. exercise at gym) } \\
\hline Gender & No & Yes & Statistics \\
\hline Girls & $87.6 \%$ & $12.4 \%$ & \multirow{3}{*}{$\begin{array}{l}X^{2}=123.47 \\
\mathbf{p}<\mathbf{0 . 0 0 0 1} *\end{array}$} \\
\hline Boys & $9.5 \%$ & $90.5 \%$ & \\
\hline Total & $47.0 \%$ & $53.0 \%$ & \\
\hline \multicolumn{4}{|c|}{ Weight control medication } \\
\hline Gender & No & Yes & Statistics \\
\hline Girls & $94.9 \%$ & $5.2 \%$ & \multirow{3}{*}{$\begin{array}{c}X^{2}=1.59 \\
p=0.2071\end{array}$} \\
\hline Boys & $98.1 \%$ & $1.9 \%$ & \\
\hline Total & $96.5 \%$ & $3.5 \%$ & \\
\hline \multicolumn{4}{|c|}{ Muscle mass increase medications } \\
\hline Gender & No & Yes & Statistics \\
\hline Girls & $99.0 \%$ & $1.0 \%$ & \multirow{3}{*}{$\begin{array}{c}X^{2}=0.26 \\
p=0.6080\end{array}$} \\
\hline Boys & $98.1 \%$ & $1.9 \%$ & \\
\hline Total & $98.5 \%$ & $1.5 \%$ & \\
\hline \multicolumn{4}{|c|}{ Laxatives } \\
\hline Gender & No & Yes & Statistics \\
\hline Girls & $96.9 \%$ & $3.1 \%$ & \multirow{3}{*}{$\begin{array}{c}X^{2}=0.29 \\
p=0.5872\end{array}$} \\
\hline Boys & $98.1 \%$ & $1.9 \%$ & \\
\hline Total & $97.5 \%$ & $2.5 \%$ & \\
\hline \multicolumn{4}{|c|}{ Diuretics } \\
\hline Gender & No & Yes & Statistics \\
\hline Girls & $95.9 \%$ & $4.1 \%$ & \multirow{3}{*}{$\begin{array}{c}X^{2}=0.24 \\
p=0.6229\end{array}$} \\
\hline Boys & $97.1 \%$ & $2.9 \%$ & \\
\hline Total & $96.5 \%$ & $3.5 \%$ & \\
\hline \multicolumn{4}{|c|}{ Anabolic steroids } \\
\hline Gender & No & Yes & Statistics \\
\hline Girls & $100.0 \%$ & $0.0 \%$ & \multirow{3}{*}{$\begin{array}{c}X^{2}=0.93 \\
p=0.3353\end{array}$} \\
\hline Boys & $99.0 \%$ & $1.0 \%$ & \\
\hline Total & $99.5 \%$ & $0.5 \%$ & \\
\hline
\end{tabular}

*-significant differences with $\mathrm{p}<0.05$

\section{The amount and frequency of eaten meals}

In the girls' group $52.6 \%$ ate 4 and more meals a day, while $42.3 \%$ ate 3 meals, and only $5.2 \%$ ate $1-2$ meals a day. In the boys' group 3 meals (48.6\%) a day dominated, however differences in the amount of meals eaten per day were not statistically significant (Tab. 5).

Table 5. The amount of eaten meals by gender

\begin{tabular}{|c|c|c|c|c|}
\hline \multicolumn{5}{|c|}{ The amount of eaten meals daily } \\
\hline Gender & $1-2$ & $\mathbf{3}$ & 4 and more & Statistics \\
\hline Girls & $5.2 \%$ & $42.3 \%$ & $52.6 \%$ & \multirow{3}{*}{$\begin{array}{c}X^{2}=1.72 \\
p=0.4226\end{array}$} \\
\hline Boys & $7.6 \%$ & $48.6 \%$ & $43.8 \%$ & \\
\hline Total & $6.5 \%$ & $45.5 \%$ & $48.0 \%$ & \\
\hline \multicolumn{5}{|c|}{ Frequency of eating breakfast } \\
\hline Gender & Everyday & Few times a week & I don't eat & Statistics \\
\hline Girls & $82.5 \%$ & $8.3 \%$ & $9.3 \%$ & \multirow{3}{*}{$\begin{array}{c}X^{2}=5.43 \\
p=0.0661\end{array}$} \\
\hline Boys & $90.5 \%$ & $7.6 \%$ & $1.9 \%$ & \\
\hline Total & $86.6 \%$ & $7.9 \%$ & $5.4 \%$ & \\
\hline \multicolumn{5}{|c|}{ Frequency of eating dinner } \\
\hline Gender & Everyday & Few times a week & I don't eat & Statistics \\
\hline Girls & $84.5 \%$ & $11.3 \%$ & $4.1 \%$ & \multirow{3}{*}{$\begin{array}{c}X^{2}=1.39 \\
p=0.4985\end{array}$} \\
\hline Boys & $89.5 \%$ & $6.7 \%$ & $3.8 \%$ & \\
\hline Total & $87.1 \%$ & $8.9 \%$ & $4.0 \%$ & \\
\hline
\end{tabular}




\begin{tabular}{|c|c|c|c|c|}
\hline \multicolumn{5}{|c|}{ Frequency of eating supper } \\
\hline Gender & Everyday & Few times a week & I don't eat & Statistics \\
\hline Girls & $80.4 \%$ & $12.4 \%$ & $7.2 \%$ & \multirow{2}{*}{$\mathrm{X}^{2}=13.66$} \\
\hline Boys & $96.2 \%$ & $3.8 \%$ & $0.0 \%$ & $\mathrm{p}=0.0011^{*}$ \\
\hline Total & $88.6 \%$ & $7.9 \%$ & $3.5 \%$ & \\
\hline
\end{tabular}

$*_{\text {-significant differences with } \mathrm{p}<0,05}$

\section{Place of eating meals}

In the girls' group, 91.5\% were characterized as eating their first meal at home, while $8.5 \%$ were eating outdoors. Dinner was eaten outdoors by $75 \%$, while $25 \%$ ate at home. Supper was eaten by $85.6 \%$ girls at home, while $14.4 \%$ ate outdoors. In the case of boys, $93.3 \%$ were characterized as eating their first meal at home, while $6.7 \%$ ate outdoors. Dinner was eaten by $76.5 \%$ outdoors, while $23.5 \%$ ate at home. Supper was classified as being eaten at home by $87.1 \%$ of students, while $12.9 \%$ ate it outdoors. There were no significant gender differences in either of places of eating meals (Tab. 6).

Table 6. The place of eating meals by gender

\begin{tabular}{|c|c|c|c|}
\hline \multicolumn{4}{|c|}{ Where do you eat breakfast? } \\
\hline Gender & At home & Outdoors & Statistics \\
\hline Women & $91.5 \%$ & $8.5 \%$ & \multirow{3}{*}{$\begin{array}{c}X^{2}=0.22 \\
p=0.6365\end{array}$} \\
\hline Men & $93.3 \%$ & $6.7 \%$ & \\
\hline Total & $92.4 \%$ & $7.6 \%$ & \\
\hline \multicolumn{4}{|c|}{ Where do you eat dinner? } \\
\hline Gender & At home & Outdoors & Statistics \\
\hline Women & $25.0 \%$ & $75.0 \%$ & \multirow{3}{*}{$\begin{array}{c}X^{2}=0.06 \\
p=0.8093\end{array}$} \\
\hline Men & $23.5 \%$ & $76.5 \%$ & \\
\hline Total & $24.2 \%$ & $75.8 \%$ & \\
\hline \multicolumn{4}{|c|}{ Where do you eat supper? } \\
\hline Gender & At home & Outdoors & Statistics \\
\hline Women & $85.6 \%$ & $14.4 \%$ & \multirow{3}{*}{$\begin{array}{c}X^{2}=0.41 \\
p=0.5241\end{array}$} \\
\hline Men & $88.6 \%$ & $11.4 \%$ & \\
\hline Total & $87.1 \%$ & $12.9 \%$ & \\
\hline
\end{tabular}

\section{Self-evaluation of shape}

In the girls' group $75.8 \%$ think about their own shape as normal, while $12.9 \%$ feel overweight, $9.7 \%$ underweight and one student felt (1.6\%) emaciation. In the boys' group $85.2 \%$ perceived their own shape as normal, $6.8 \%$ felt underweight, $4.5 \%$ overweight and 3 people felt (3.4\%) emaciation. There were no significant differences present among genders in terms of self-evaluation (Tab. 7, Fig. 3).

Table 7. Self-evaluation of shape by gender

\begin{tabular}{|c|c|c|c|c|c|}
\hline Gender & Emaciation & Underweight & Proper weight & Overweight & Gender differentiation \\
\hline Women & $1(1.6 \%)$ & $6(9.7 \%)$ & $47(75.8 \%)$ & $8(12.9 \%)$ & $X^{2}=5.66$ \\
\cline { 1 - 4 } Men & $3(3.4 \%)$ & $6(6.8 \%)$ & $75(85.2 \%)$ & $4(4.5 \%)$ & $\mathrm{p}=0.1291$ \\
\hline Total & $4(2.7 \%)$ & $12(8.0 \%)$ & $122(81.3 \%)$ & $12(8.0 \%)$ & \multicolumn{1}{c}{} \\
\cline { 1 - 4 }
\end{tabular}




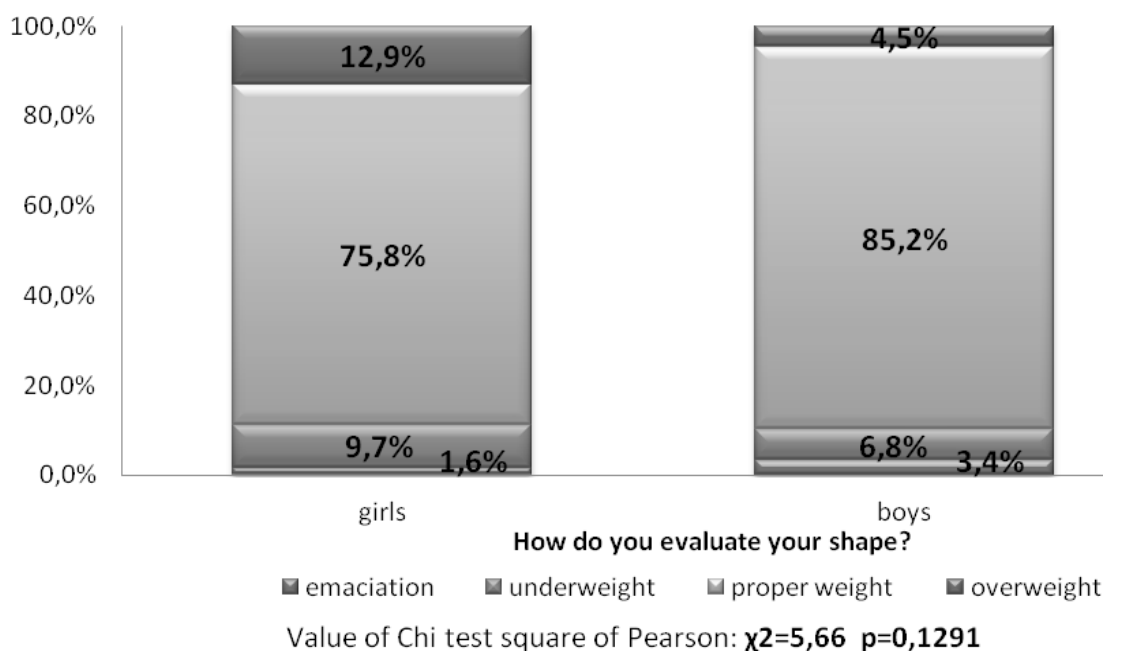

Figure 3. Self-evaluation of shape by gender

\section{Meals-related behaviours}

Meals-related behaviours have been presented in Table 8. In the girls' group half of them (50.5\%) have snacks between meals. Significantly fewer boys have snacks between meals $(25.7 \%)$. The difference in this kind of behaviour is statistically significant. Around $20 \%$ of respondents eat at nights and this kind of habit is similar in both genders. Respondents in a clear majority tend to feel satiety (74.8\%) and this is no different either among boys or girls. Consequently, only $15.3 \%$ claimed that they feel hunger every day. Similarly, in this behaviour there were no significant differences among genders. Where it comes to surfeit of food, most of the students (52\%) claimed to feel that way less than once a week. This feeling occurred only among $3 \%$. Similarly in this kind of habits there were no significant differences among boys and girls. (Tab. 8).

Table 8. Meals-related behaviours by gender

\begin{tabular}{|c|c|c|c|c|c|}
\hline \multicolumn{6}{|c|}{ Do you have snacks between meals? } \\
\hline Gender & \multicolumn{2}{|c|}{ No } & \multicolumn{2}{|c|}{ Yes } & Statistics \\
\hline Women & \multicolumn{2}{|c|}{$49.5 \%$} & \multicolumn{2}{|c|}{$50.5 \%$} & \multirow{3}{*}{$\begin{array}{l}X^{2}=13.22 \\
p=0.0003\end{array}$} \\
\hline Men & \multicolumn{2}{|c|}{$74.3 \%$} & \multicolumn{2}{|c|}{$25.7 \%$} & \\
\hline Total & \multicolumn{2}{|c|}{$62.4 \%$} & \multicolumn{2}{|c|}{$37.6 \%$} & \\
\hline \multicolumn{6}{|c|}{ Are there days when you are snacking at nights? } \\
\hline Gender & \multicolumn{2}{|c|}{ No } & \multicolumn{2}{|c|}{ Yes } & Statistics \\
\hline Women & \multicolumn{2}{|c|}{$82.5 \%$} & \multicolumn{2}{|c|}{$17.5 \%$} & \multirow{3}{*}{$\begin{array}{c}X^{2}=0.38 \\
p=0.5376\end{array}$} \\
\hline Men & \multicolumn{2}{|c|}{$79.1 \%$} & \multicolumn{2}{|c|}{$21.0 \%$} & \\
\hline Total & \multicolumn{2}{|c|}{$80.7 \%$} & \multicolumn{2}{|c|}{$19.3 \%$} & \\
\hline \multicolumn{6}{|c|}{ How many times a week do you feel satiety? } \\
\hline Gender & Less than once & 1-2 times & 3-4 times & Everyday & Statistics \\
\hline Women & $1.0 \%$ & $7.2 \%$ & $20.6 \%$ & $71.1 \%$ & \multirow{3}{*}{$\begin{array}{c}X^{2}=6.88 \\
p=0.0758\end{array}$} \\
\hline Men & $4.8 \%$ & $7.6 \%$ & $9.5 \%$ & $78.1 \%$ & \\
\hline Total & $3.0 \%$ & $7.4 \%$ & $14.9 \%$ & $74.8 \%$ & \\
\hline \multicolumn{6}{|c|}{ How many times a week do you feel hunger? } \\
\hline Gender & Less than once & 1-2 times & 3-4 times & Everyday & Statistics \\
\hline Women & $51.6 \%$ & $21.7 \%$ & $10.3 \%$ & $16.5 \%$ & \multirow{3}{*}{$\begin{array}{c}X^{2}=0.45 \\
p=0.9304\end{array}$} \\
\hline Men & $53.3 \%$ & $20.0 \%$ & $12.4 \%$ & $14.3 \%$ & \\
\hline Total & $52.5 \%$ & $20.8 \%$ & $11.4 \%$ & $15.3 \%$ & \\
\hline \multicolumn{6}{|c|}{ How many times a week do you feel surfeit of food? } \\
\hline Gender & Less than once & 1-2 times & 3-4 times & Everyday & Statistics \\
\hline Women & $54.6 \%$ & $35.1 \%$ & $6.2 \%$ & $4.1 \%$ & \multirow{3}{*}{$\begin{array}{c}X^{2}=1.89 \\
p=0.5947\end{array}$} \\
\hline Men & $49.5 \%$ & $42.9 \%$ & $5.7 \%$ & $1.9 \%$ & \\
\hline Total & $52.0 \%$ & $39.1 \%$ & $5.9 \%$ & $3.0 \%$ & \\
\hline
\end{tabular}

\footnotetext{
*-significant differences with $\mathrm{p}<0,05$
} 


\section{Students' physical activity}

Boys are significantly more physically active - 3124 MET, than girls - 2790 MET. Boys tends to have higher values in each area of activity than girls, respectively: intensive activity 999 MET to 829 MET (statistically significant), moderate 951 MET to 885 MET, walking 1174 MET to 1077 MET. (Tab. 9-10, Fig. 4).

Table 9. Means and standard deviations of physical activity areas depending on the gender of respondents (in MET-min/ week.).

\begin{tabular}{|c|c|c|c|}
\hline Amount of physical activity & Girls & Boys & Total \\
\hline Complete activity & $2789.9 \pm 776.7$ & $3124.0 \pm 968.1$ & $2963.6 \pm 895.0$ \\
\hline Intensive activity & $828.7 \pm 508.6$ & $999.2 \pm 530.0$ & $917.4 \pm 525.5$ \\
\hline Moderate activity & $884.5 \pm 346.2$ & $950.9 \pm 473.7$ & $919.0 \pm 417.7$ \\
\hline Walking & $1076.7 \pm 366.8$ & $1173.9 \pm 504.1$ & $1127.2 \pm 445.1$ \\
\hline
\end{tabular}

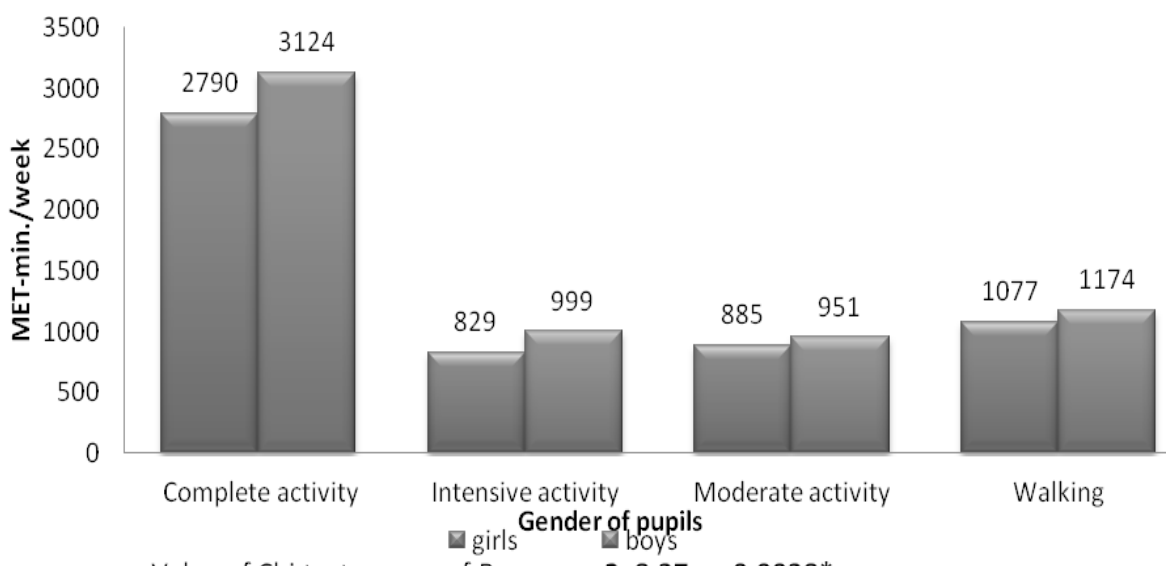

*-significant differences with $\mathrm{p}<0,05$

Value of Chi test square of Pearson: $\chi 2=8,37 \mathrm{p}=0,0038^{*}$

Figure 4. Areas of physical activities of students by respondents' gender

Table 10. Differentiation of areas of physical activities of students by respondents' gender

\begin{tabular}{|c|c|c|}
\hline \multicolumn{2}{|c|}{ U Mann-Whitney's Test } & p \\
\hline Amount of physical activity & $\mathbf{Z}$ & $0.0062^{*}$ \\
\hline Complete activity & -2.74 & $0.0000^{*}$ \\
\hline Intensive activity & -4.19 & 0.9596 \\
\hline Moderate activity & -0.05 & 0.0587 \\
\hline Walking & -1.89 & \\
\hline
\end{tabular}

*-significant differences with $\mathrm{p}<0,05$

\section{Discussion}

According to the results of scientific research it is assumed that nutritional habits and physical activity are vital elements of a lifestyle. Among nutritional habits one ought to emphasize, among others, the role of quantity and regularity of meals taking an optimal number of them as 4-5 times a day [3]. In case of examined students only a little more than half of female students (52.6\%) and less male students (43.8\%) consume this number of meals. Similar results were obtained among the youth of Świętokrzyskie voivodeship [28]. It is stressed out that the most important meal should be a nutritious breakfast that will cover $20-25 \%$ of daily body energetic requirement [3]. The frequency of eating the main three meals per day among the respondents was similar and was around $90 \%$. In the breakfast case the indicator of whole-day nourishment was higher among boys (90.5\%) than girls $(82.5 \%)$, and these are rather favourable results when compared to the results received from Silesia voivodeship's youth in Poland [8].

Among other nutritional habits it is worth mentioning that significant differences in willingness to lose weight are favourable among girls and to increase weight (improving muscles) are favourable among boys. When it comes to agents used to improve shape, girls significantly more often exercise in order to lose body 
weight, however boys significantly more often exercise to increase body weight (musculature). The analyzed behaviours prove that girls take care of their health more. A positive phenomenon is that both genders use very little such agents as a weight control medication, diuretics and anabolic steroids. In general terms, one might note that Latvia's youth are characterized by proper nutritional habits taking into account gender differences.

Furthermore, physical activity was measured by widely acknowledged in studies International Physical Activity Questionnaire [29] and the results are more favourable among boys, which is a confirmation of the previous national $[13,14,15,16]$ and foreign $[17,18,23,24]$ research among the school youth.

To sum up, one may state when it comes to health-promoting behaviours, female students are characterized by more favourable nutritional habits, and boys are better at physical activity, which is a confirmation of research of Poznań schools students [30].

\section{References:}

1. Hollmann W, Strűderbh K. Excercise, physical activity, nutrition and the brain. Nutrition Rev. 1996; 54: $37-43$.

2. Malina RM. Tracking of physical fitness cross the lifespan. Res Q Exerc Spor. 1996; 67(3): 48-57.

3. Chabros E, Charzewska J, Rogalska-Niedźwiedź M, Wajszczyk B, Chwojnowska Z, Fabiszewska J. Mała aktywność fizyczna młodzieży w wieku pokwitania sprzyja rozwojowi otyłości. Probl Hig Epidemiol. 2008; 89(1): 58-61 (in Polish).

4. Gacek M. Wiedza i zachowania żywieniowe młodzieży uprawiającej sport w szkole mistrzostwa sportowego w Krakowie. Rocz Panstw Zakl Hig 2007, 58(4): 641-648 (in Polish).

5. Wołowski T, Jankowska M. Wybrane aspekty zachowań zdrowotnych młodzieży gimnazjalnej. Część I. Zachowania młodzieży związane z odżywianiem. Probl Hig Epidemiol. 2007; 88(1): 64-68 (in Polish).

6. Kołłątaj B, Kołłątaj W, Karwat ID. Nieprawidłowe nawyki żywieniowe u nastolatków - badania wstępne. Probl Hig Epidemiol. 2008; 9(3): 395-400 (in Polish).

7. Gajda R, Jeżewska-Zychowicz M. Nutritional behaviours of adolescents living in the Świętokrzyskie voivodeship. Probl Hig Epidemiol. 2010; 91(4): 611-617.

8. Sitko D, Wojtaś M, Gronowska-Senger A. Sposób żywienia młodzieży gimnazjalnej i licealnej, Rocz Panstw Zakl Hig. 2012; 63(3): 319-327 (in Polish).

9. Kiciak A, Całyniuk B, Grochowska-Niedworok E, Kardas M, Dul L. Zachowania żywieniowe młodzieży z województwa śląskiego, Med. Og Nauk Zdr. 2014; 20(3): 296-300 (in Polish).

10. Mazur J, Małkowska-Szkutnik A. Wyniki badań HBSC 2010. Raport techniczny. Warszawa: Instytut Matki i Dziecka; 2011; 85-109 (in Polish).

11. Kołoło H. Poczucie własnej skuteczności, wsparcie społeczne i samoocena jako determinanty aktywności fizycznej młodzieży. Praca doktorska, Warszawa: AWF; 2010 (in Polish).

12. Piątkowska M, Pec K, Pec T. Aktywność fizyczna młodzieży w wieku ponadgimnazjalnym, Wychowanie Fizyczne i Zdrowotne. 2007; 8-9: 30-33 (in Polish).

13. Rozpara M, Mynarski W, Czapla K. Szacowanie kosztu energetycznego aktywności fizycznej na podstawie badań kwestionariusza IPAQ. In: Mynarski W., editor. Teoretyczne i empiryczne zagadnienia rekreacji i turystyki. Katowice: Akademia Wychowania Fizycznego; 2008: 272-279 (in Polish).

14. Biernat E. Aktywność fizyczna mieszkańców Warszawy. Na przykładzie wybranych grup zawodowych. Warszawa: Oficyna Wydawnicza, Szkoła Głowna Handlowa; 2011 (in Polish).

15. Nawrocka A, Grabara M. Dymorfizm płciowy w aktywności fizycznej uczniów z katowickich liceów, Zeszyty Metodyczno-Naukowe. AWF Katowice. 2012; 1: 20-25 (in Polish).

16. Bergier J, Kapka-Skrzypczak L, Biliński P, Paprzycki P, Wojtyła A. Physical activity of Polish adolescents and young adult according to IPAQ: a population based study, Annals of Agricultural and Environmental Medicine. 2012; 19(1): 109-115.

17. Wasilewska M, Bergier J. Eating habits of adolescents in Poland and in other countries. Health Problems of Civilization. 2015; 9(4): 40-48

18. Bergier B, Bergier J, Wojtyła A. Various aspects of physical activity among Lithuanian adolescents, Annals of Agricultural Environmental Medicine. 2012; 19(4): 775-779.

19. Frömel K, Górna K. Aktywność ruchowa dzieci i młodzieży regionu śląskiego. W: Mynarski W, Ponczek M., editors. Tradycje i współczesność kultury fizycznej, Katowice: AWF; 2001: 51-68.

20. Mitáš J, Nykodým J, Frömel K. Physical activity and sedentary behavior in 14-15 year old students with regard to location of school. Acta Univ. Palacki. Olomuc., Gymn. 2009; 39(3): 7-11.

21. Merkiel S, Chalcarz W, Deptula M. Comparison of physical activity and favourite ways of spending free time in preschool girls and boys from the Mazowsze region, Rocz Panstw Zakl Hig. 2011; 62(1): 93-99. 
22. Cocca A, Liukkonen J, Mayorga-Vega D, Viciana-Ramirez J. Health-related physical activity levels in Spanish youth and young adults. Perceptual \& Motor Skills: Physical Development \& Measurement. 2014; 118, 1: 247260.

23. Pelegrini A, Silva DAS, Claumann GS, Cardoso TE, Ferreira de Lima e Silva JM, Petroski EL. Practice of walking, moderate and vigorous physical activity and associated factors in adolescents from a state capital of southern Brazil. Rev Bras Cineantropom Desempenho Hum 2015, 17(1): 11-20.

24. Rangul V, Holmen TL, Kurtze N, Cuypers K, Midthjell K. Reliability and validity of two frequently used selfadministered physical activity questionnaires in adolescents. BMC Med Res Methodol 2008;8: 47-57.

25. Craig CL, Marsall AL, Sjostrom M, Bauman AE, Booth ML, Ainsworth BE, Pratt M, Elund U, Yngve A, Sallis JF, Oja P. International Physical Activity Questionaire: 12-Country Reliability and Validity, Med. Sci. Sport Exerc. 2003; 35: 1381-1395.

26. Maddison R, Ni Mhurchu C, Jiang Y, Hoorn SV, Rodgers A, Lawes CMM., International Physical Activity Questionnaire (IPAQ) and New Zealand Physical Activity Questionnaire (NZPAQ): A doubly labelled water validation. Int J Behav Nutr and Phys. 2007; 4: 62.

27. Bauman A, Bull F, Chey T, Craig CL, Ainsworth BE, Sallis JF, Bowles HR, Hagstromer M, Sjostrom M, Pratt M, Ips Group.,The International Prevalence Study on Physical Activity: results from 20 countries. Int. J. Behavioral Nutrition and Physical Activity, 6(1), 21.

28. Gajda R., Jeżewska-Zychowicz M. Zachowania żywieniowe młodziezy mieszkającej w województwie świetokrzyskim- wybrane aspekty. Probl. Hig. Epidemiol. 2010; 91(4): 611-617 (in Polish).

29. Booth ML. Assessment of Physical Activity: An International Perspective, Res. Quart. Exerc. Sport. 2000; 71: 114-120.

30. Łagowska K, Woźniewicz M, Jeszka J. Porównanie nawyków żywieniowych młodzieży z uwzglednieniem płci oraz poziomu aktywności fizycznej. Rocz Panstw Zakl Hig. 2011; 62(3): 335-342 (in Polish). 